\title{
COMPARATIVE FOURIER TRANSFORM INFRARED AND X-RAY POWDER DIFFRACTION ANALYSIS OF NATURALLY OCCURRED K-FELDSPARS
}

\author{
Theodosoglou E. ${ }^{1}$, Koroneos A. ${ }^{1}$, Soldatos T. ${ }^{1}$, Zorba T. ${ }^{2}$, \\ and Paraskevopoulos K. M. ${ }^{2}$ \\ ${ }^{1}$ School of Geology, Aristotle University of Thessaloniki, 54124 Thessaloniki - Greece, \\ eltheod@geo.auth.gr,koroneos@geo.auth.gr, soldatos@geo.auth.gr \\ ${ }^{2}$ Department of Physics, Aristotle University of Thessaloniki, 54124 Thessaloniki - Greece, \\ zorba@auth.gr,kpar@auth.gr
}

\begin{abstract}
Natural K-feldspars from igneous rocks have been examined by means of X-ray powder diffraction (XRPD) and Fourier transform infrared (FTIR) spectroscopy in the spectral range 400-1400 $\mathrm{cm}^{-1}$, where the Si-Al-O bonds exhibit the dominant vibrations. From the XRPD analysis three species have been distinguished, i.e. microclines (3 samples), orthoclases (4 samples) and sanidines (3 samples); their unit cell parameters were calculated. The FTIR transmittance spectra of all samples have common bands at 426, 463, 584, 604, 726 and $772 \mathrm{~cm}^{-1}$ and some additional features. The spectra of sanidine and orthoclase exhibit fewer and broader bands than the microclines', especially in the area 1000-1200 $\mathrm{cm}^{-1}$. The differences in their spectra are located in four bands. The bands at around 536-538 and 646-648 $\mathrm{cm}^{-1}$ in the spectrum of microcline, are shifted at around 542-544 and $640-642 \mathrm{~cm}^{-1}$ in the spectrum of orthoclase and at around 546 and $636 \mathrm{~cm}^{-1}$ in the spectrum of sanidine. Four bands at 1010, 1050, 1090 and $1136 \mathrm{~cm}^{-1}$ in the spectra of microcline are substituted with two quite broad bands at about 1030 and $1125 \mathrm{~cm}^{-1}$ in the spectra of orthoclase and sanidine. These differences are attributed to different degree of Al-Si ordering in the structure of K-feldspars.
\end{abstract}

Keywords: microcline, orthoclase, sanidine, FTIR, XRPD.

\section{Introduction}

One of the most common and well-examined mineral groups is feldspars. Several studies have been carried out concerning their structure, with various methods as X-ray powder diffraction (XRPD) and Fourier transform infrared spectroscopy (FTIR) and plenty of data have been produced (Barth, 1964; Hovis, 1986; Harris et al., 1989, Kronenberg et al., 1996; Zhang et al., 1997). However, the majority of the FTIR research has been focused on synthetic and/or single crystals. A small number of natural feldspar FTIR studies have been focused on single crystals and even fewer on powdered material. In this paper, naturally occurring K-feldspars from igneous rocks of Northern Greece are identified and classified with the X-ray diffraction techniques and their FTIR spectra are investigated. The aim of this paper is to present the first results of a comparative XRPD-FTIR study of the structure (unit cell parameters) and FTIR spectra of the K-feldspars. 
Table 1. Classification of the samples.

\begin{tabular}{|c|c|c|c|c|}
\hline Sample & Origin & Rock & $\begin{array}{c}\text { Identification } \\
\text { based on XRPD }\end{array}$ & \\
\hline S 1 & N. Almopia & Latite & Sanidine & \\
\hline S 2 & Samothraki & Rhyodacite & Sanidine & $\begin{array}{c}\text { sample BR-02 } \\
\text { Koroneos and Christofides } \\
(1985)\end{array}$ \\
\hline S 3 & Samothraki & Rhyodacite & Sanidine & $\begin{array}{c}\text { sample BR-03 } \\
\text { Koroneos and Christofides } \\
(1985)\end{array}$ \\
\hline $\mathrm{O} 1$ & Xanthi & Granodiorite & Orthoclase & $\begin{array}{c}\text { sample } 162 \\
\text { (Christofides, 1977) }\end{array}$ \\
\hline $\mathrm{O} 2$ & Xanthi & Monzonite & Orthoclase & $\begin{array}{c}\text { sample } 232 \\
\text { (Christofides, 1977) }\end{array}$ \\
\hline O 3 & $\begin{array}{l}\text { Maronia, } \\
\text { Komotini }\end{array}$ & $\begin{array}{l}\text { Qtz Monzogab- } \\
\text { bro }\end{array}$ & Orthoclase & $\begin{array}{c}\text { sample MR-62 } \\
\text { (Papadopoulou, 2002) }\end{array}$ \\
\hline $\mathrm{O} 4$ & $\begin{array}{l}\text { Maronia, } \\
\text { Komotini }\end{array}$ & $\begin{array}{l}\text { Qtz Monzogab- } \\
\text { bro }\end{array}$ & Orthoclase & $\begin{array}{c}\text { sample MR-74 } \\
\text { (Papadopoulou, 2002) }\end{array}$ \\
\hline M 1 & Elatia, Drama & Bi Granodiorite P. & Microcline & $\begin{array}{c}\text { sample } 162 \\
\text { (Soldatos, 1985) }\end{array}$ \\
\hline M 2 & Kastoria & $\begin{array}{l}\mathrm{Hb}-\mathrm{Bi} \text { Granodior- } \\
\text { ite }\end{array}$ & Microcline & $\begin{array}{c}\text { sample TH-17 } \\
\text { (Grigoriadou, 2001) }\end{array}$ \\
\hline M 3 & Sithonia & $\begin{array}{l}\text { Two Mica Gran- } \\
\text { ite }\end{array}$ & Microcline & $\begin{array}{c}\text { sample } 100 \\
\text { (D’Amico et al., 1990) }\end{array}$ \\
\hline
\end{tabular}

\section{Materials and Methods}

\subsection{Samples}

The samples studied here are K-feldspars from various plutonic and volcanic rocks of Northern Greece (Table 1).

The K-feldspars were separated from the mafic minerals of the igneous rocks using a Franz model L-1 magnetic separator. Then, the K-feldspars were separated from the rest sialic minerals using the Sodium Polytungstate (SPT) heavy liquid with a density of 2.58. Quartz, plagioclases and most of the perthitic phase were sunk and all the floating material was pure K-feldspar including some microperthitic phase. In cases where zeolites were present their separation was succeeded with the SPT heavy liquid having density 2.54 . The grain size used for the separations was 100 to $150 \mu \mathrm{m}$. The pure K-feldspar concentrates were prepared by grinding them in an agate mortar to a size less than $63 \mu \mathrm{m}$. Concentrates with grain size between 20 and $63 \mu \mathrm{m}$ were used for FTIR analysis and concentrates with size less than $20 \mu \mathrm{m}$ were used for the XRPD analysis. 


\subsection{X-Ray Powder Diffraction (XRPD)}

XRPD patterns were obtained on a PHILIPS PW 1820/00 X-ray diffractometer of the Department of Mineralogy-Petrology-Economic Geology, School of Geology, A.U.Th., equipped with a PW 1710 microprocessor and using PC-APD software. Operating conditions for all samples were $35 \mathrm{kV}$ and $25 \mathrm{~mA}$ using Ni-filtered $\mathrm{CuK}_{\text {ave }}$ radiation. The 2theta $(2 \theta)$ scanning range was between 3 and $63^{\circ}$ and the scanning speed was $0.6 \% \mathrm{~min}$. The identification of the samples was made using the JCPDS-ICDD 2003 database. The calculations of the unit cell parameters (Table 2), as well as the refinements were made with CHECKCELL software. Silicon was used as external standard. The probability of $\mathrm{Al}$-cation to occupy one of the $\mathrm{T} 1$ sites $\left(\mathrm{t}_{1} 0+\mathrm{t}_{1} \mathrm{~m}\right)$ was calculated from Luth's equation (eq. 1) (Stewart and Wright, 1974).

$$
\mathrm{T}_{1}=\mathrm{t}_{1} 0+\mathrm{t}_{1} \mathrm{~m}=\frac{\mathrm{c}-0.45132 * \mathrm{~b}-1.22032}{1.6095-0.11252 * \mathrm{~b}}
$$

\subsection{Fourier Transform Infrared Spectroscopy (FTIR)}

For the FTIR analysis the sample was homogenized with $\mathrm{KBr}$ with a ratio 1:100 (1.8 $\mathrm{mg}$ of the sample was homogenized with $180 \mathrm{mg} \mathrm{KBr}$ ). The mixture was pressed for 3 minutes at 4 tn and for 10 minutes at $7 \mathrm{tn}$ using a hydraulic hand press in an evacuated die into a $13 \mathrm{~mm}$ pellet. The pellets were dried at $110{ }^{\circ} \mathrm{C}$ for 48 hours just before the collection of the spectra to avoid taking the spectra of the atmospheric water. The FTIR spectra in transmittance mode were recorded in the region of mid IR (MIR, 400 to $1400 \mathrm{~cm}^{-1}$ ) and represent the average of 128 scans with resolution $2 \mathrm{~cm}^{-1}$ with a PERKIN-ELMER FTIR Spectrometer Spectrum1000 of the Solid State Physics Section, Physics Department, A.U.Th. As a reference was used a pure KBr pellet weighted $180 \mathrm{mg}$.

\section{Results}

\subsection{XRPD}

Representative XRPD patterns of the samples are presented in Fig. 1, their identification based on the ICCD patterns and their calculated unit cell parameters are presented in Tables 1 and 2, respectively. According to the XRPD patterns of the samples they are divided in three species: sanidines $(\mathrm{S} 1, \mathrm{~S} 2, \mathrm{~S} 3)$, orthoclases $(\mathrm{O} 1, \mathrm{O} 2, \mathrm{O} 3, \mathrm{O} 4)$ and microclines $(\mathrm{M} 1, \mathrm{M} 2, \mathrm{M} 3)$. It must be noted here that in some samples a small amount of albite is observed. This is due to the concentration of albite in a perthitic form. Perthitic and microperthitic textures were observed under the petrographic microscope in the studied samples. In a better look this amount is present in the samples which had microperthites whereas the samples with perthites present almost pure $\mathrm{K}$ phase. The cause is the grain size of the samples during the heavy liquid separation. The rich-in-perthites particles were sunk but the poor-in-perthites ones were floated and mixed with the pure K end-member phase.

\subsection{FTIR}

In the mid-FTIR spectra $\left(400-1400 \mathrm{~cm}^{-1}\right)$, the vibrations of $\mathrm{Si}$ and $\mathrm{Al}$ bonds with $\mathrm{O}$ in the structure of minerals (Si-O, Si-O-Si, Si-O-Al, etc.) are mainly observed (Figs 2a, b, c).

The spectra of all samples (Figs 2a, b, c) present six common bands at around 426, 463, 584, 604, 726 and $772 \mathrm{~cm}^{-1}$ (Table 3). In the spectral region from 1000 to $1200 \mathrm{~cm}^{-1}$ there are two quite broad bands, which in some samples appear to be split into four. The band at about $426 \mathrm{~cm}^{-1}$ in all sam- 
Table 2. Unit cell parameters of the examined samples calculated from the XRPD data.

\begin{tabular}{|c|c|c|c|c|c|c|c|}
\hline Sample & $\boldsymbol{A}(\boldsymbol{\AA})$ & $\boldsymbol{b}(\boldsymbol{\AA})$ & $\boldsymbol{c}\left(\boldsymbol{\AA}^{\mathrm{A}}\right)$ & $\boldsymbol{\alpha}\left({ }^{\boldsymbol{o}}\right)$ & $\boldsymbol{\beta}\left({ }^{\circ}\right)$ & $\boldsymbol{\gamma}\left({ }^{\circ}\right)$ & $\boldsymbol{t}_{\boldsymbol{l}} \mathbf{0 + t _ { 1 } \boldsymbol { m }}$ \\
\hline S 1 & 8.3586 & 13.0021 & 7.1627 & 90.00 & 116.23 & 90.00 & 0.507 \\
\hline S 2 & 8.3661 & 13.0027 & 7.1620 & 90.00 & 116.29 & 90.00 & 0.501 \\
\hline S 3 & 8.4714 & 12.9891 & 7.1716 & 90.00 & 116.13 & 90.00 & 0.602 \\
\hline O 1 & 8.5546 & 12.9706 & 7.1737 & 90.00 & 116.02 & 90.00 & 0.663 \\
\hline O 2 & 8.5585 & 12.9680 & 7.1686 & 90.00 & 116.00 & 90.00 & 0.636 \\
\hline O 3 & 8.5412 & 12.9662 & 7.1683 & 90.00 & 115.99 & 90.00 & 0.638 \\
\hline O 4 & 8.5593 & 12.9838 & 7.1954 & 90.00 & 116.01 & 90.00 & 0.776 \\
\hline M 1 & 8.5230 & 12.8981 & 7.1940 & 90.39 & 115.88 & 88.85 & 0.964 \\
\hline M 2 & 8.5685 & 12.9452 & 7.2177 & 90.67 & 115.96 & 87.78 & 1.013 \\
\hline M 3 & 8.5571 & 12.9635 & 7.2172 & 90.73 & 115.93 & 87.75 & 0.969 \\
\hline
\end{tabular}

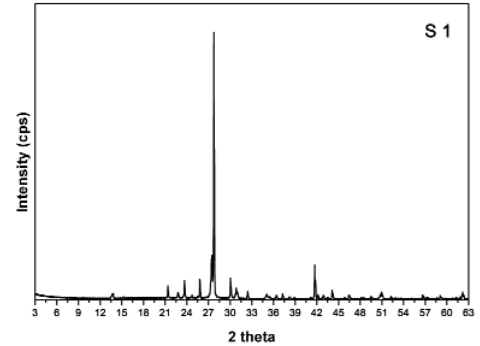

(a)

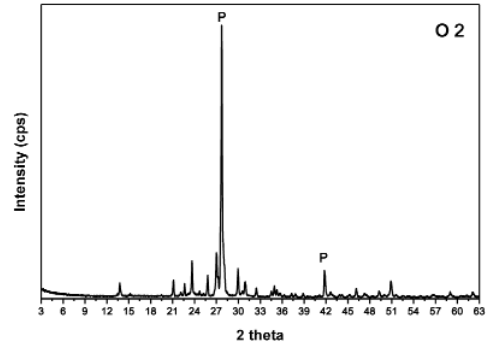

(c)

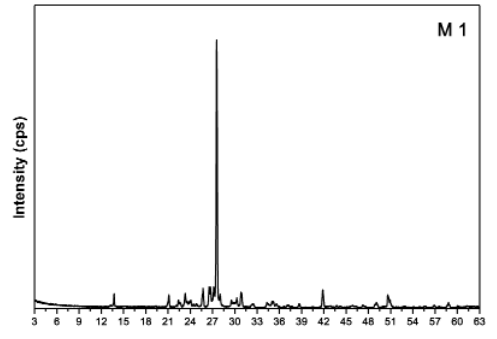

2 theta

(e)

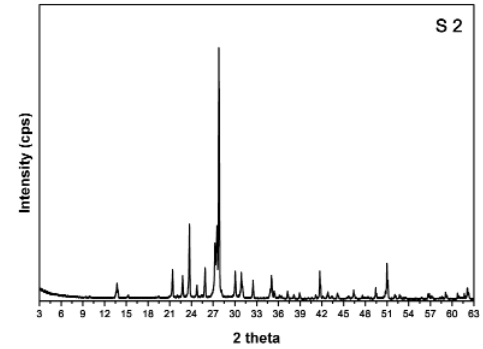

(b)

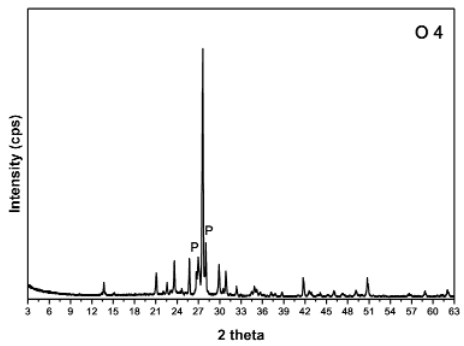

(d)

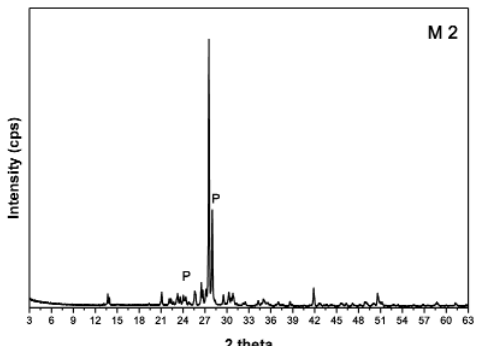

(f)

Fig. 1: Representative XRPD patterns (S: sanidine, O: orthoclase, M: microcline, P: Perthite) 


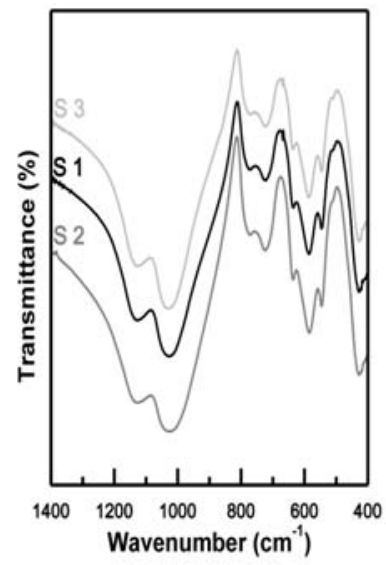

(a)

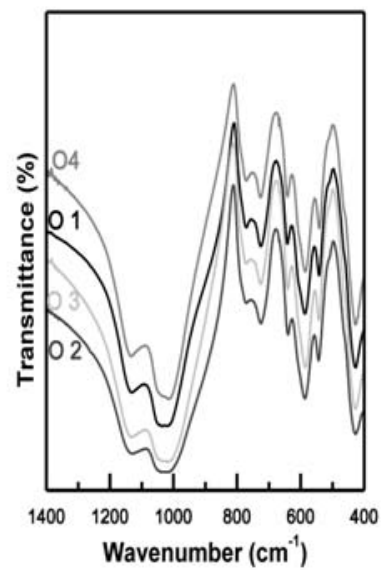

(b)

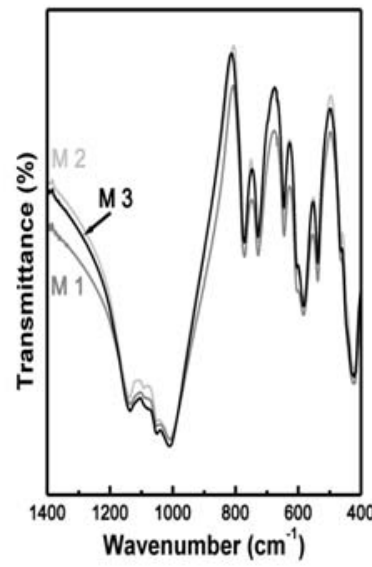

(c)

Fig. 2: FTIR spectra of the examined samples (S: sanidine, O: orthoclase, M: microcline).

ples is attributed to the O-Si-O deformation (Iiishi et al., 1971; Matteson and Herron, 1993). The band observed at about $463 \mathrm{~cm}^{-1}$ is due to the coupling of O-Si-O bending and the $\mathrm{K}-\mathrm{O}$ stretching vibrations (Iiishi et al., 1971; Matteson and Herron, 1993). The bands at about 584 and $604 \mathrm{~cm}^{-1}$ are correlated to the $\mathrm{O}-\mathrm{Si}(\mathrm{Al})-\mathrm{O}$ bending vibrations of the three species. The bands at about 463 and 604 $\mathrm{cm}^{-1}$ appear as weak bands in all microcline spectra and as shoulders in all orthoclase spectra; in the sanidine spectra they are hardly distinguished. The bands at 726 and $772 \mathrm{~cm}^{-1}$ are, respectively, attributed to the $\mathrm{Si}-\mathrm{Al}(\mathrm{Si})$ and the $\mathrm{Si}-\mathrm{Si}$ stretching vibrations of the three species (Iiishi et al., 1971; Matteson and Herron, 1993). Also, in all samples two broad bands in the spectral areas 1010-1050 $\mathrm{cm}^{-1}$ and 1090-1136 $\mathrm{cm}^{-1}$ occur. Besides the afore-mentioned common bands, each K-feldspar species exhibits the following additional features:

\section{Sanidine}

The spectra of sanidines reveal two additional bands at around 546 and $636 \mathrm{~cm}^{-1}$, not present in the spectra of orthoclases and microclines (Fig. 3, Table 3). The band at around $546 \mathrm{~cm}^{-1}$ is attributed to the coupling between the $\mathrm{O}-\mathrm{Si}-\mathrm{O}$ bending vibration and the $\mathrm{K}-\mathrm{O}$ stretching vibration, whereas the band at $636 \mathrm{~cm}^{-1}$ corresponds to the O-Si(Al)-O bending vibrations (Iiishi et al., 1971; Matteson and Herron, 1993). Two quite broad bands are observed at about 1030 and $1125 \mathrm{~cm}^{-1}$. These bands are due to the $\mathrm{Si}-\mathrm{O}$ stretching vibration and especially the band at $1030 \mathrm{~cm}^{-1}$ may, also, be attributed to the $\mathrm{Si}(\mathrm{Al})-\mathrm{O}$ stretching vibrations.

\section{Orthoclase}

In the spectra of all orthoclases, the $546 \mathrm{~cm}^{-1}$ band appeared in the spectra of sanidines is slightly shifted to lower wavenumbers at about $543 \mathrm{~cm}^{-1}$ (Fig. 3, Table 3). This band is due to the coupling between the O-Si-O bending vibration and the K-O stretching vibration (Iiishi et al., 1971; Matteson and Herron, 1993). Concerning the $636 \mathrm{~cm}^{-1}$ band in sanidines, it is shifted to higher wavenumbers at about $640-642 \mathrm{~cm}^{-1}$ in the spectra of all orthoclase samples. This band is attributed to the O-Si(Al)-O bending vibrations (Iiishi et al., 1971; Matteson and Herron, 1993). Additionally, there 
Table 3. Observed frequencies $\left(\mathrm{cm}^{-1}\right)$ of the FTIR spectra for sanidine, orthoclase and microcline samples and their attribution.

\begin{tabular}{|c|c|c|c|c|}
\hline & Common & Sanidine & Orthoclase & Microcline \\
\hline 426 & O-Si-O deformation & & & \\
\hline 463 & $\begin{array}{l}\text { coupling between } \\
\text { O-Si-O bending } \\
\text { and K-O stretching } \\
\text { vibrations }\end{array}$ & & & \\
\hline $\begin{array}{c}536- \\
538\end{array}$ & & & & $\begin{array}{l}\text { coupling between } \\
\text { O-Si-O bending } \\
\text { and } \mathrm{K}-\mathrm{O} \text { stretching } \\
\text { vibrations }\end{array}$ \\
\hline $\begin{array}{c}542- \\
544\end{array}$ & & & $\begin{array}{l}\text { coupling between } \\
\text { O-Si-O bending } \\
\text { and } \mathrm{K}-\mathrm{O} \text { stretching } \\
\text { vibrations }\end{array}$ & \\
\hline 546 & & $\begin{array}{l}\text { coupling between } \mathrm{O}- \\
\text { Si-O bending } \\
\text { and } \mathrm{K}-\mathrm{O} \text { stretching } \\
\text { vibrations }\end{array}$ & & \\
\hline $\begin{array}{l}584 \\
604 \\
\end{array}$ & $\begin{array}{c}\mathrm{O}-\mathrm{Si}(\mathrm{Al})-\mathrm{O} \text { bending } \\
\text { vibrations }\end{array}$ & & & \\
\hline 636 & & $\begin{array}{l}\mathrm{O}-\mathrm{Si}(\mathrm{Al})-\mathrm{O} \text { bending vi- } \\
\text { brations }\end{array}$ & & \\
\hline $\begin{array}{c}640- \\
642\end{array}$ & & & $\begin{array}{l}\mathrm{O}-\mathrm{Si}(\mathrm{Al})-\mathrm{O} \text { bending } \\
\text { vibrations }\end{array}$ & \\
\hline $\begin{array}{c}646- \\
648\end{array}$ & & & & $\begin{array}{c}\mathrm{O}-\mathrm{Si}(\mathrm{Al})-\mathrm{O} \text { bending vi- } \\
\text { brations }\end{array}$ \\
\hline $\begin{array}{l}726 \\
772 \\
\end{array}$ & $\begin{array}{l}\mathrm{Si}-\mathrm{Si}(\mathrm{Al}) \text { and } \mathrm{Si}-\mathrm{Si} \\
\text { stretching vibrations }\end{array}$ & & & \\
\hline 1010 & & & & $\begin{array}{c}\mathrm{Si}(\mathrm{Al})-\mathrm{O} \text { stretching vi- } \\
\text { bration }\end{array}$ \\
\hline 1030 & & $\begin{array}{l}\mathrm{Si}(\mathrm{Al})-\mathrm{O} \text { and } \mathrm{Si}-\mathrm{O} \\
\text { stretching vibrations }\end{array}$ & $\begin{array}{l}\mathrm{Si}(\mathrm{Al})-\mathrm{O} \text { and } \mathrm{Si}-\mathrm{O} \\
\text { stretching vibrations }\end{array}$ & \\
\hline 1050 & & & & $\begin{array}{c}\mathrm{Si}(\mathrm{Al})-\mathrm{O} \text { stretching vi- } \\
\text { brations }\end{array}$ \\
\hline 1090 & & & & $\begin{array}{l}\text { Si-O stretching } \\
\text { vibration }\end{array}$ \\
\hline 1125 & & $\begin{array}{l}\text { Si-O stretching } \\
\text { vibration }\end{array}$ & $\begin{array}{l}\text { Si-O stretching } \\
\text { vibration }\end{array}$ & \\
\hline 1136 & & & & $\begin{array}{l}\text { Si-O stretching } \\
\text { vibration }\end{array}$ \\
\hline
\end{tabular}


are two broad bands, one at about $1030 \mathrm{~cm}^{-1}$ attributed to the $\mathrm{Si}-\mathrm{O}$ and $\mathrm{Si}(\mathrm{Al})-\mathrm{O}$ stretching vibrations and a second one at about $1125 \mathrm{~cm}^{-1}$ due to the $\mathrm{Si}-\mathrm{O}$ stretching vibration.

\section{Microcline}

The spectra of microclines present a band at about 536-538 $\mathrm{cm}^{-1}$ (Fig. 3, Table 3) which is attributed to the coupling between the $\mathrm{O}-\mathrm{Si}-\mathrm{O}$ bending vibration and the $\mathrm{K}-\mathrm{O}$ stretching vibration and it is shifted to lower wavenumbers than the bands in orthoclases and sanidines attributed to the same vibrations (Iiishi et al., 1971; Matteson and Herron, 1993). An inverse behavior presents the band that is appeared at about $646-648 \mathrm{~cm}^{-1}$ in the spectra of microclines. This band is attributed to the O$\mathrm{Si}(\mathrm{Al})-\mathrm{O}$ bending vibrations and is shifted to higher wavenumbers than the bands attributed to the same vibrations in the spectra of orthoclases and sanidines (Iiishi et al., 1971; Matteson and Herron, 1993). Another important difference in the spectra of microclines is the presence of four sharp bands in the region between 1000 and $1200 \mathrm{~cm}^{-1}$ instead of only two broad bands in the spectra of orthoclases and sanidines. The bands at around 1010 and $1050 \mathrm{~cm}^{-1}$ are both attributed to the $\mathrm{Si}(\mathrm{Al})-\mathrm{O}$ stretching vibrations. The broad band at around $1090 \mathrm{~cm}^{-1}$ and a sharper one at around $1136 \mathrm{~cm}^{-1}$ are attributed to the Si-O stretching vibration (Iiishi et al., 1971; Couty and Velde, 1986).

\section{Discussion}

The basic structure of an alkali-feldspar consists of a three dimensional array of corner-sharing tetrahedra. Three of the four cation sites in their unit cell are occupied by Si-cation and the fourth by Alcation. The high temperature forms of $\mathrm{KAlSi}_{3} \mathrm{O}_{8}$, sanidine and perhaps orthoclase are monoclinic $(\mathrm{C} 2 / \mathrm{m})$ and the low temperature form, microcline, is triclinic $(\mathrm{C} \overline{\mathrm{I}})$. The $\mathrm{K}$-feldspars rarely approximate the end-member composition and usually have a relatively high content of $\mathrm{NaAlSi}_{3} \mathrm{O}_{8}$. $\mathrm{Al}$ though $\mathrm{K}$ and $\mathrm{Na}$ form a continuous solid solution series at high temperatures, on slow cooling unmixing takes place and the isomorphous series is destroyed. The solid solution is separated into two phases, a K-rich phase and a Na-rich one. The new texture generated from this unmixing is called cryptoperthitic, microperthitic or perthitic, depending on the size of the Na-rich areas. The new Na-rich phase into the K-rich phase is called cryptoperthite, microperthite or perthite, respectively (Deer et al., 1971; Smith and Brown, 1988). In some of the examined samples the presence of perthite is obvious, as revealed by the XRPD analysis combined with the petrographical data.

The infrared spectra of the investigated samples show quite common features. This observation is in agreement with Laves and Hafner (1956), Hafner and Laves (1957) and Martin (1970) observation for the infrared spectra of alkali-feldspars. The low temperature microclines and consequently highly ordered, show spectra with sharp and easily distinguished bands. On the other hand, the high temperature and presumably disordered sanidines have spectra with much broader and fewer bands, observed also by White (1974) and Moenke (1974). These aspects are correlated with the A1/Si disorder of the K-feldspars (Laves and Hafner, 1956; Hafner and Laves, 1957; Moenke, 1974). These, also, are observed in the spectra of the examined samples. All of the sanidine spectra have broader bands than the orthoclases and they have less and broader bands than the microclines.

All of the investigated samples present six common bands at $426 \mathrm{~cm}^{-1}$ (O-Si-O bending vibration), $584 \mathrm{~cm}^{-1}$ [O-Si(Al)-O bending vibrations], $726 \mathrm{~cm}^{-1}$ [Si-Si(Al) stretching vibrations] and $772 \mathrm{~cm}^{-1}$ ( $\mathrm{Si}$-Si stretching vibration). Of special interest and further investigation is the presence of two bands at around 463 and $604 \mathrm{~cm}^{-1}$. In the spectra of microclines, these two bands appear as sharp and weak bands. The spectra of orthoclaces present shoulders in the 463 and $604 \mathrm{~cm}^{-1}$, whereas in the spectra of sanidines there is only an indication of the presence of these two bands. This behavior may be at- 


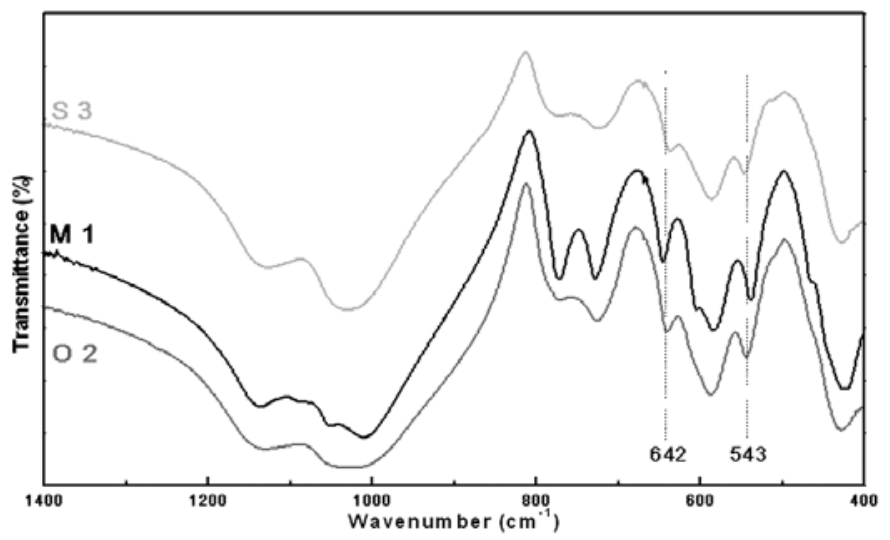

Fig. 3: FTIR spectra of representative samples of each species. The two vertical lines represent the exact positions of 542-544 and 640-642 $\mathrm{cm}^{-1}$ bands of orthoclase. Samples as in Fig. 1.

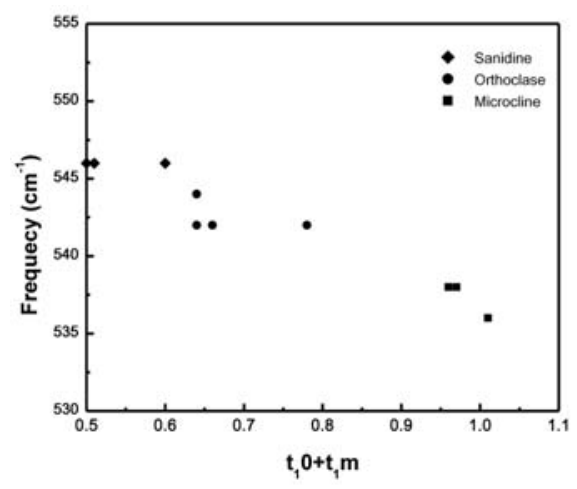

(a)

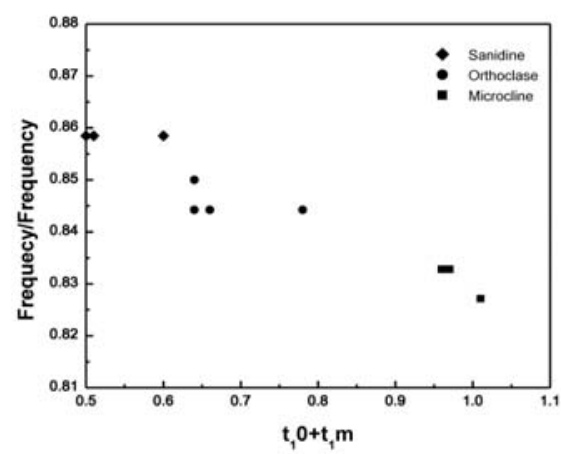

(c)

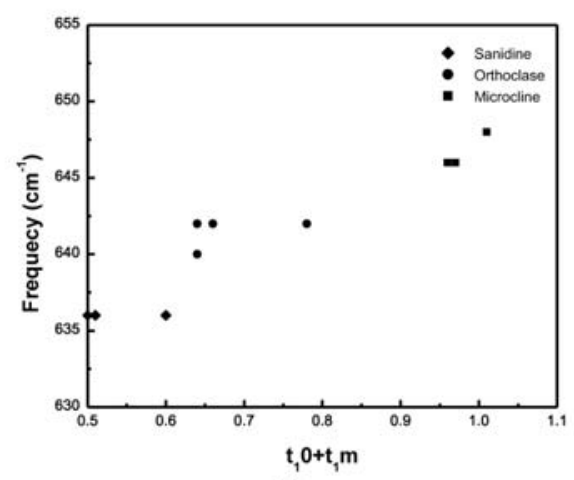

(b)

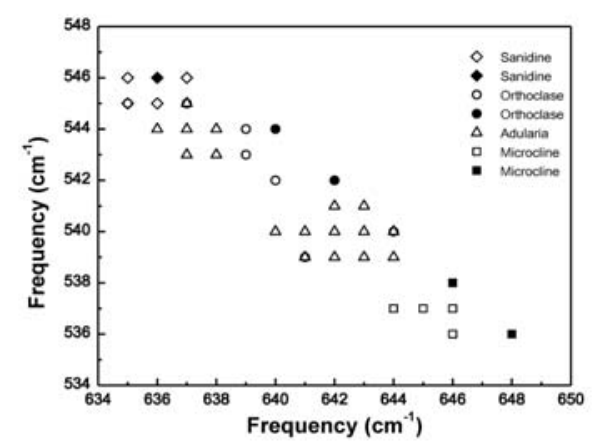

(d)

Fig. 4: a. First order-sensitive band versus $t_{1} 0+t_{1} m$. b. Second order-sensitive band versus $t_{1} 0+t_{1} m$. c. Ratio of the first to second order-sensitive band versus $t_{1} 0+t_{1} m$. d. Frequency/frequency diagram, after White (1974), showing the relation of the two sharp order-sensitive bands in the FTIR spectra of the samples. Data of the open symbols from Hafner and Laves (1957) are plotted for comparison along with the investigated samples (filled symbols). 
tributed to the degree of ordering in the samples. Microclines, which present a good degree of ordering, exhibit sharper and distinct bands, whereas sanidines, which present the most disordered structure of the K-feldspars, appear only indications of their presence. Orthoclases, an intermediate phase, present shoulders in their spectra in these wavenumbers making certain their presence. Two common but very broad bands in the range of 1000 to $1200 \mathrm{~cm}^{-1}$ are attributed mainly to the Si-O stretching vibration.

The main differences in the spectra of the three species are the position of two bands that are shifted and associated with the $\mathrm{O}-\mathrm{Si}-\mathrm{O}$ bending vibration. These bands are correlated with the degree of ordering in the feldspars (Hafner and Laves, 1957; Harris et al., 1989; Matteson and Herron, 1993). The first order-sensitive band, appeared at around $546 \mathrm{~cm}^{-1}$ in the spectra of sanidines, is attributed to the coupling of O-Si-O bending and the $\mathrm{K}-\mathrm{O}$ stretching vibrations and is shifted to lower wavenumbers at around 542-544 $\mathrm{cm}^{-1}$ in the spectra of orthoclases and at around 536-538 $\mathrm{cm}^{-1}$ in the spectra of microclines. The second order-sensitive band is observed at around $636 \mathrm{~cm}^{-1}$ in the spectra of sanidines and is attributed to the $\mathrm{O}-\mathrm{Si}(\mathrm{Al})-\mathrm{O}$ bending vibrations. This band is shifted to higher wavenumbers at around 640-642 and 646-648 $\mathrm{cm}^{-1}$ in the spectra of orthoclases and microclines, respectively. The plot of each order-sensitive band versus $t_{1} 0+t_{1} m$ is presented in Figures $4 a$ and $b$. In Figure $4 \mathrm{a}$ it is observed that as the probability of Al-cation to occupy the T1 site increases, the first order-sensitive band shifts to lower wavenumbers. The opposite trend is observed in Figure $4 \mathrm{~b}$ where the probability of T1 site to be occupied by Al-cation increases when the second order-sensitive band shifts to higher wavenumbers. In Figure $4 \mathrm{c}$ is presented the ratio of the first to second ordersensitive band versus $\mathrm{t}_{1} 0+\mathrm{t}_{1} \mathrm{~m}$. Increasing the $\mathrm{t}_{1} 0+\mathrm{t}_{1} \mathrm{~m}$, the ratio of these bands is decreasing. This observation is in agreement with the aspects of Hafner and Laves (1957), Harris et al. (1989) and Matteson and Herron (1993). In Figure 4d are presented the two order-sensitive bands in a frequency-frequency diagram. In the same diagram are presented data from natural K-feldspars from Hafner and Laves (1957) to compare the samples from Northern Greece to K-feldspars of other igneous rocks all around the world. The plot of the samples from Hafner and Laves (1957) is in agreement with the results of the samples investigated in this paper.

From the diagram of Figure $4 \mathrm{~d}$ it is concluded that the frequency/frequency ratio is higher in the most disordered $\mathrm{K}$-feldspars (sanidines), with the lowest $\mathrm{t}_{1} 0+\mathrm{t}_{1} \mathrm{~m}$, and lower in the most ordered ones (microclines), with the higher $\mathrm{t}_{1} 0+\mathrm{t}_{1} \mathrm{~m}$. Orthoclases which are an intermediate form, have ratios in between those of sanidines and microclines.

\section{Acknowledgments}

We would like to thank G. Christofides, G. Eleftheriadis and L. Papadopoulou who offered the samples from Xanthi, Almopia and Maronia respectively, as well as the anonymous reviewer for the very constructive comments, improving the quality of the paper. Also, the first author would like to thank the State Scholarships Foundation of Greece for financial support.

\section{References}

Barth, T.F.W., 1964. On the constitution of the alkali-feldspars. Tschermaks min. u.petr. Mitt., Bd. 10, H. 1-4, 14-33.

Christofides, G., 1977. Contribution to the study of the plutonic rocks of Xanthi area. PhD Thesis, Aristotle University of Thessaloniki, 249pp.

Couty, R., \& Velde, B., 1986. Pressure-induced band splitting in infrared spectra of sanidine and albite. Am. Mineral., 71, 99-104. 
D’ Amico, C., Christofides, G., Eleftheriadis, G., Bargossi, G. M., Campana, R. \& Soldatos, T., 1990. The Sithonia Plutonic Complex (Chalkidiki, Greece). Miner. Petr. Acta, XXXIII, 177.

Deer, W.A., Howie, R.A. \& Zussman, J., 1971. Rock forming minerals, Vol. 4. Framework silicates. London, Longman Group, 435pp.

Grigoriadou, A., 2001. Mineralogy of Kastoria pluton. Diploma Thesis, Aristotle University of Thessaloniki, 57pp.

Hafner, S. \& Laves, F., 1957. Ordnung/Unordnung und Ultrarotabsorption II. Variation der Lage und Intensität einiger Absorptionen von Feldspäten. Z. Kristallogr., 109, 204-225.

Harris, M.J., Saljie, E.K.H., Güttler, B.K. \& Carpenter, M.A., 1989. Structural states of natural potassium feldspar: An infrared spectroscopic study. Phys. Chem. Minerals, 16, 649-658.

Hovis G.L., 1986. Behavior of alkali feldspars: Crystallographic properties and characterization of composition and Al-Si distribution. Am. Mineral., 71, 869-890.

Iiishi, K., Tomisaka, T., Kato, T., Yamaguchi \& Umegaki, Y., 1971. Isomorphous substitution and infrared and far infrared spectra of the feldspar group. N. Jb. Miner. Abh., 115, 1, 98-119.

Koroneos, A. \& Christofides, G., 1985. Preliminary investigation on Al, Si distribution in K-feldspars from Samothraki island (N. Aegean Sea). Mineral Wealth, 37, 27-32.

Kronenberg, A.K., Yund, R.A. \& Rossman, G.R., 1996. Stationary and mobile hydrogen defects in potassium feldspar. Geochim. Cosmochim. Acta, 60, 4075-4094.

Laves, F. \& Hafner, S., 1956. Ordnung/Unordnung und Ultrarotabsorption I. (Al,Si)-Verteilung in Feldspäten. Z. Kristallogr., 108, 52-63.

Martin, R.F., 1970. Cell parameters and infrared absorption of synthetic high to low albites. Contr. Mineral. Petrol., 26, 62-74.

Matteson, A. \& Herron, M.M., 1993. End-member feldspar concentrations determined by FTIR spectral analysis. Journal of Sedimentary Petrology, 63(6), 1144-1148.

Moenke, H.H.W., 1974. Silica, the three-dimensional silicates, borosilicates and beryllium silicates. In Farmer, V. C. (ed). The infra-red spectra of minerals. 365-382, London, Mineralogical Society, 539pp.

Papadopoulou, L., 2002. Mineral phase equilibria, crystallization condition and evolution of Maronia pluton, Thrace, Greece. PhD Thesis, Aristotle University of Thessaloniki, 336pp.

Smith, J.V. \& Brown, W.L., 1988. Feldspar minerals, Vol. 1. Crystal structures, physical, chemical and microtextural properties. Berlin, Springen Verlag, 828pp.

Soldatos, T., 1985. Petrology and Geochemistry of the Elatia Plutonite (Central Rhodope, Macedonia, N. Greece). Ph. D. thesis, Univ. of Thessaloniki, $320 \mathrm{pp}$.

Stewart, D.B \&Wright, T.L., 1974. Al/Si order and symmetry of natural alkali feldspars, and the relationship of strained cell parameters to bulk composition. Bull. Soc. Minéral. Cristallogr., 97, 356-377.

White, W.B., 1974. Order-Disorder effects. In Farmer, V. C. (ed). The infra-red spectra of minerals. $87-$ 110, London, Mineralogical Society, 539pp.

Zhang, M., Salje, E.K.H., Carpenter, M.A., Parsons, I., Kroll H., Reed, S.J.B. \& Graeme-Barber, A., 1997. Exsolution and Al-Si disorder in alkali feldspars: Their analysis by infrared spectroscopy. Am . Mineral., 82, 849-857. 